\title{
Nutritional improvement of pasta with Pereskia aculeata Miller: a non-conventional edible vegetable
}

\author{
Rie SATO ${ }^{1}$, Lilian Pinheiro de Lima CILLI ${ }^{1}$, Beatriz Ewert de OLIVEIRA ${ }^{1}$, Vinicius Borges Vieira MACIEL ${ }^{2}$, \\ Anna Cecília VENTURINI ${ }^{1 \star}$, Cristiana Maria Pedroso YOSHIDA ${ }^{1}$
}

\begin{abstract}
Nutritionally enhanced pasta was developed by adding dried leaves of Pereskia aculeata Miller, known as ora-pro-nobis (OPN). The OPN are edible wild plants, underused and unknow plants. The incorporation of OPN dried leaves flour (OPN-F) into a regularly eaten food product, such as pasta, could be a healthy and low-cost strategy to improve nutrient intake and promote an exploration into a new fresh market food. The aim of this study was to develop a pasta product containing OPN-F, improving the protein, dietary fibre, calcium and iron intake and characterize its physico-chemical and sensorial aspects. The addition of OPN-F decreased the cooking loss and increased significantly the dietary fibre and ash content, as well as calcium and iron, as compared to conventional pasta. An alternative and healthy application of non-conventional edible vegetable proposed was greatly accepted $(80.0 \%)$ by the potentials consumers.
\end{abstract}

Keywords: ora-pro-nobis; non-conventional food plant; sensorial analysis; tagliatelle.

Practical Application: The consumers are interested in minimally processed foods with fewer preservatives, higher quality and safety. Then, in this study, a tagliatelle pasta enriched a non-conventional edible vegetable kwon ora-pro-nobis was developed. The resultant pasta product rich in protein, dietary fibre, iron and calcium could be used as an alternative to traditional pasta, increasing their nutritional value.

\section{Introduction}

Consumers have been demanding higher quality of life. Nutritional diet intake affects directly the wellbeing and health. Supplying adequate human nutrition within ecosystem carrying capacities is a key factor in the global environmental sustainability challenge (Heller et al., 2013). Among the possibilities to improve the nutrient availability are found the non-conventional food plants. They are wild edible plants, with low cost, easily accessible and have high nutritional potential. Pereskia aculeata Miller or known in Brazil such as ora-pro-nobis (OPN) or American gooseberry, is an example of a non-conventional food plant. It is a vegetable that play no part in the general population diet, being often underused and unknown (Kinupp \& Lorenzi, 2014). OPN is native plant widely distributed in the Central and South America and southern region of United States belonging to the Cactaceae family (Conceição et al., 2014; Takeiti et al., 2009). In Brazil, OPN is found from the northeast (Bahia) to the southern region (Minas Gerais, Paraná, Santa Catarina and Rio Grande do Sul) of the country (Conceição et al., 2014). The main useful part of OPN is the leaf due to its source of protein, total dietary fibre (especially soluble fibre), minerals (calcium, magnesium, manganese, zinc and iron) and vitamins (Takeiti et al., 2009). The high-quality of protein, fibre contents and absence of leaf toxicity of the OPN leaves make it a useful and important food source (Dayrell \& Vieira, 1977). OPN is the so-called 'meat of the poor' due to the high content of proteins in its leaves (Mercê et al.,
2001). In addition to presenting a well-balanced composition, the leaves have a high content of L-lysine. The presence of this amino acid is important, since lysine is an essential amino acid, and in general, it is deficient in cereals (Pinto \& Scio, 2014). The most abundant amino acid found in OPN is tryptophan, representing over $20 \%$ of its amino acids (Nobel \& Hartsock, 1986). Furthermore, the protein and essential amino acid levels reported are substantially higher than the minimum amount recommended by the Food and Agriculture Organization of the United Nations (FAO) as necessary for human consumption (Sierakowski et al., 1987). As a comparison, meat has approximately $20 \%$ of protein; and studies conducted by Sierakowski et al. (1987) with OPN leaves show that they are composed of $25 \%$ protein. Almeida \& Cambraia (1974) reported protein content in OPN leaves higher than common vegetables sources, such as common corn $(7.6-10 \%, w / w)$, beans $(18-20 \%, w / w)$, spinach $(2.2 \%, \mathrm{w} / \mathrm{w})$, kale $(1.6 \%, \mathrm{w} / \mathrm{w})$ and lettuce $(1.3 \%, \mathrm{w} / \mathrm{w})$.

Pasta products are largely popular worldwide and well accepted because of their sensory attributes. Its convenience and palatability make it a popular dish (Padalino et al., 2013). Conventional pasta is mainly manufactured using wheat flour as the primary ingredient (Khan et al., 2013). Pasta is a source of carbohydrates (74-78\%, dry basis), $11-13 \%$ of proteins, but its deficient in lysine and threonine (Abdel-Aal \& Hucl, 2002). 
A fortification to increase the pro-healthy quality of this product would be useful. Pasta may represent an excellent model as a food vehicle for the addition of specific nutrients (Tazrart et al., 2016; Miceli et al., 2015; Khan et al., 2013). The incorporation of vegetables into pasta could significantly contribute to the recommended daily vegetable intake (Oliviero \& Fogliano, 2016).

Petitot et al. (2010) produced fortified spaghetti by adding high amounts of legume flour (35\% of split pea) improving the proteins, fibres, and vitamins content. Sun-Waterhouse et al. (2013) developed fettuccine pastas enriched with plant-derived bioactives, dietary fibre from Hi-maize starch and polyphenols from elderberry juice concentrate offering a healthy benefit to consumers. Sobrinho et al. (2015) incorporated $2 \%$ (w/w) of OPN leaves flour in sausage formulations, enhancing the nutritional aspect. A tagliatelle pasta containing different concentrations of flour made from OPN leaves $(1.0,1.5,2.0 \%, \mathrm{w} / \mathrm{w})$ formed a firm and elastic dough with no cracks (Rocha et al., 2008).

The objective of this study was to develop a functional pasta (tagliatelle) incorporating flour of OPN obtained from dried leaves and to evaluate its effect on pasta quality, colour, $\mathrm{pH}$, firmness, weight gain, cooking loss and sensorial acceptance.

\section{Materials and methods}

\subsection{Materials}

Wheat flour (Nita, Santos, Brazil), white eggs in natura type A (Qualitá, São Paulo, Brazil), olive oil (La Violetera, Curitiba, Brazil) and salt (Lebre, Areia Branca, Brazil) were purchased from local commerce (São Paulo, Brazil). OPN flour was purchased from Flora Bioativa Farm (Flora Bioativa, Santa Catarina, Brazil). The leaves of OPN were dried in an oven at $60^{\circ} \mathrm{C}$ and triturated to form the OPN flour (information provided by Flora Bioativa).

\subsection{Methods}

\section{Preparation of pasta enriched with OPN-F}

Sieved wheat flour and beaten eggs in a ratio 2:1 (flour:eggs) were homogenized. The mixture was mixed by hand for $15 \mathrm{~min}$, and then passed on smooth cylinder until the formation of a thin blade size nine, smooth and not crumbly. The dough sheet was cut into pasta form, and then arranged in aluminium moulds to be taken to dry in an oven with air circulation (Tecnal, model SL 102/200, Piracicaba, Brazil) at $60{ }^{\circ} \mathrm{C}$ for $40 \mathrm{~min}$. The added amounts of OPN-F were $10 \%$ (F1) and $20 \%$ (F2) related to wheat flour weight (Table 1). All experiments were carried out in triplicate.

Table 1. Formulation of pasta enriched with different concentrations of ora-pro-nobis leaves flour (OPN-F), maintaining an ingredient ratio of 2:1 (liquid:solid).

\begin{tabular}{cccc}
\hline Formulations & \multicolumn{3}{c}{ Ingredients } \\
\cline { 2 - 4 } & $\begin{array}{c}\text { Wheat flour } \\
(\mathrm{g})\end{array}$ & $\begin{array}{c}\text { OPN-F } \\
(\mathrm{g})\end{array}$ & $\begin{array}{c}\text { Beaten eggs } \\
(\mathrm{mL})\end{array}$ \\
\hline Control (without OPN-F) & 100 & 0 & 50 \\
F1 (OPN-F 10\%) & 100 & 10 & 55 \\
F2 (OPN-F 20\%) & 100 & 20 & 60 \\
\hline
\end{tabular}

\section{Nutritional profile: OPN-F and pasta}

Chemical analysis: Analyses of moisture, ash, lipid (Soxhlet method), protein (Kjeldahl method) content were performed according to the standard AOAC method (Association of Official Analytical Chemists, 2012). The content of calcium and iron was determined using method 974.3 from the Association of Official Analytical Chemists (2012). The dietary fibre content was determined according to AOAC method - Official method 985.29 (Association of Official Analytical Chemists, 2012). The dietary fibre content of F1 and F2 were estimated based on the formulation, addition of $10 \%$ of OPN-F and $20 \%$ of OPN-F, respectively. The $\mathrm{pH}$ was measured in cooked pasta sample (10 g mixed in $100 \mathrm{~mL}$ of distilled water) using a calibrated device (Digimed, model DM-22, Brazil).

\section{Pasta quality}

Firmness: the maximum force required to cut the pasta strands represented it. It was determined by using a texturometer (Brookfield, model CT3, Middleboro, USA). The cooked pasta strands were washed with $50 \mathrm{~mL}$ of water and kept in $300 \mathrm{~mL}$ of cold water for $1 \mathrm{~min}$, and then cut to $10 \mathrm{~cm}$ lengths. The TA-52 MOHRS probe was used with the following conditions: pre-test speed: $2.0 \mathrm{~mm} \mathrm{~s}^{-1}$, test speed: $0.5 \mathrm{~mm} \mathrm{~s}^{-1}$, post-test speed: $0.5 \mathrm{~mm} \mathrm{~s}^{-1}$ and with $50 \%$ compression. Weight gain: it was determined based on Paucar-Menacho et al. (2008). Weight gain was calculated based on the weight before and after the cooking process ( $200 \mathrm{~mL}$ of boiling water for $4 \mathrm{~min}$ ). Cooking loss: it was calculated by evaporating $25 \mathrm{~mL}$ of cooking water in an oven at $105^{\circ} \mathrm{C}$ (Tecnal, model TE-394-1, Piracicaba, Brazil) until a constant weight was reached (Paucar-Menacho et al., 2008). Colour parameters: The surface colour parameters were measured after the cooking process. A colourimeter (Konica Minolta, CR400 Chroma Meter model, Tokyo, Japan) was used. It was calibrated with a white plate, an observation angle of $2^{\circ}$ and illuminant D65. Measurements were performed using the CIE L* $\mathrm{a}^{*} \mathrm{~b}^{\star}$ system (Maciel et al., 2015).

\section{Sensorial analysis}

A complete balanced block design for three experimental products was used to minimize order effects. The sensorial analysis was carried out with a total of 100 judges of different ages and social classes, both sexes, selected randomly among the staff and students from the university, who had no prior knowledge of the formulation of the products (Stone \& Sidel, 2004). This process was registered in the ethics committee as CAAE: 53738716.0.0000.5505. The cooked samples were coded with random numbers of three digits and presented to the judge. The test began with three questions in order to check whether any of the judges had any prior experience with OPN and the frequency of pasta consumption. The three pasta formulations were evaluated for colour, odour, flavour, texture, appearance parameters and overall impression using a nine-point structured hedonic scale, where $1=$ very much dislike and $9=$ very much like. Consumer purchase intention was evaluated by assessing the possibility that consumers would plan or be willing to purchase the product, using a five-point scale. The acceptance of the product (F1 and F2) was calculated from the average of 
the scores given by the judges, considering the five-point-scale, and a score equal to 5 represents $100 \%$ probability of buying.

\subsection{Statistical analysis}

The data were analysed through the analysis of variance (ANOVA) using the Statistics program version 7.0 (Statistics Inc., USA). Differences between the means were detected by Tukey's multiple comparisons test (95\% confidence).

\section{Results and discussion}

\subsection{Preparation of pasta enriched with OPN-F}

The pasta containing $10 \%$ and $20 \%$ of OPN-F presented a green colour due to the pigment of the leaves (complex mixture of many forms of chlorophyll and carotenoid pigments) (Figure 1). Preliminary tests were carried out adding 10, 20, 30, 40 and $50 \%$ of OPN-F related to wheat flour weight. Pasta containing OPN-F concentrations above $30 \%$ (related to wheat flour weight)
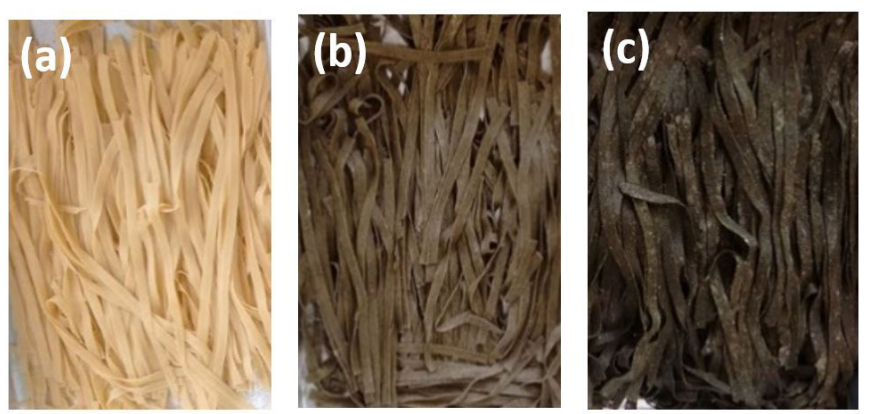

Figure 1. Typical appearance of the different dried pasta (tagliatelle) enriched with dried ora-pro-nobis leaves flour (OPN-F) at different concentrations in function of wheat flour (in weight): (a) control; (b) F1 (10\%); and (c) F2 (20\%). did not form continuous and soft gluten dough. This indicate that the amount of OPN-F compromised the formation of a three-dimensional gluten matrix

After being cooked in boiling water ( $4 \mathrm{~min}$ ), it was not observed visually colour difference in cooked water. It could be associated that the pigment did not migrate to the water. On the other hand, the cooked OPN pasta was not sticky and brittle, which could be due to the starch molecules being entrapped in the OPN fibres. The interference of fibre with the gluten-protein network of pasta can result in the destruction of the protein-starch matrix and an uneven distribution of water in the pasta's structure. During the cooking of the pasta, the starch will compete with the fibre for water molecules; so high fibre content will mean that the starch will absorb less water (Ficco et al., 2016). Krishnan et al. (2012) observed a decrease in the stickiness of the dough in pasta with a higher content of fibre achieved by adding sweet potato.

\subsection{Chemical composition and energy value}

The chemical composition of dehydrated OPN-F and the pasta samples (control, F1 and F2) were determined (Table 2). The dietary fibre content of the pasta containing $10 \%$ and $20 \%$ of OPN-F was approximately three and five-fold higher than the conventional pasta (control, without OPN-F), respectively. The pasta enriched with OPN-F is an alternative to improve the fibre intake in human diet, promoting healthy effects. Fibre in the diet increases satiety, which reduces the quantity of food ingested and regulates the intestine's metabolism. The World Health Organization recommendation is that fibre intake should be 20 to $30 \mathrm{~g} \mathrm{day}^{-1}$. The consumption of $100 \mathrm{~g}$ of F1 and F2, will provide 30.3 and $50.8 \%$ of total fibre intake, respectively. Khan et al. (2013) indicated a health functional property of pasta formulated with red sorghum flour due to the higher total dietary fibre content (twice as compared to pasta formulated

Table 2. Centesimal composition (dry basis) of ora-pro-nobis leaves flour (OPN-F) and pasta samples (control, F1 and F2).

\begin{tabular}{|c|c|c|c|c|}
\hline \multirow{2}{*}{ Composition } & \multirow{2}{*}{ OPN-F } & \multicolumn{3}{|c|}{ Pasta } \\
\hline & & Control & F1 & $\mathrm{F} 2$ \\
\hline Moisture content (\%) & $7.51 \pm 0.03$ & $6.88 \pm 0.42^{\mathrm{a}}$ & $6.83 \pm 0.48^{\mathrm{a}}$ & $6.14 \pm 0.56^{\mathrm{a}}$ \\
\hline Lipids (\%) & $3.50 \pm 0.00$ & $7.22 \pm 0.29^{\mathrm{a}}$ & $7.24 \pm 0.51^{\mathrm{a}}$ & $7.62 \pm 0.58^{\mathrm{a}}$ \\
\hline Proteins (\%) & $12.36 \pm 0.14$ & $19.79 \pm 0.09^{\mathrm{a}}$ & $19.86 \pm 0.09^{\mathrm{a}}$ & $19.60 \pm 0.20^{\mathrm{a}}$ \\
\hline Dietary fibre (\%) & $41.77 \pm 0.44$ & $1.89 \pm 0.05^{\mathrm{a}}$ & $6.06^{1}$ & $10.23^{1}$ \\
\hline Ash (\%) & $15.22 \pm 0.16$ & $1.02 \pm 0.07^{c}$ & $2.16 \pm 0.06^{\mathrm{a}}$ & $5.00 \pm 0.08^{\mathrm{b}}$ \\
\hline Carbohydrates (by difference) & 58.96 & 65.09 & 63.91 & 61.64 \\
\hline Calcium (\%) & $3.66 \pm 0.20$ & $0.05 \pm 0.00^{c}$ & $0.41 \pm 0.01^{\mathrm{b}}$ & $1.18 \pm 0.01^{\mathrm{a}}$ \\
\hline Iron $\left(\mathrm{mg} \mathrm{kg}^{-1}\right)$ & $386.90 \pm 2.60$ & $32.45 \pm 0.64^{c}$ & $48.28 \pm 0.28^{\mathrm{b}}$ & $61.38 \pm 0.74^{\mathrm{a}}$ \\
\hline Sulphur (\%) & $0.85 \pm 0.20$ & - & - & - \\
\hline Magnesium (\%) & $2.56 \pm 0.20$ & - & - & - \\
\hline Sodium $\left(\mathrm{mg} \mathrm{kg}^{-1}\right)$ & $247.33 \pm 0.40$ & - & - & - \\
\hline Potassium (\%) & $2.88 \pm 0.30$ & - & - & - \\
\hline Phosphorus $\left(\mathrm{g} \mathrm{kg}^{-1}\right)$ & $1.50 \pm 0.10$ & - & - & - \\
\hline $\mathrm{pH}$ & - & $7.13^{\mathrm{b}}$ & $7.16^{\mathrm{b}}$ & $7.36^{\mathrm{a}}$ \\
\hline 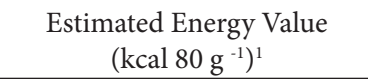 & & 317.10 & 289.95 & 301.29 \\
\hline
\end{tabular}

Media with different letters in the same line are significant different by Tukey's test ( $\mathrm{p}<0.05)$; ${ }^{1}$ Estimated value based on the formulation: addition of $10 \%$ of OPN-F (F1) and $20 \%$ of OPN-F (F2). 
with durum wheat semolina). An enriched salt bread with OPN flour increased fibre content as compared to conventional bread (Silva et al., 2015).

The three formulations of pasta showed comparable values of lipid content. The ash content of F1 and F2 was significantly higher than control pasta, twice and five times, respectively. The addition of OPN-F improved significantly the calcium and iron content. In comparison with conventional pasta, the mineral content of pasta containing OPN-F could be considered a nutritional advantage. Calcium is an important mineral in the human metabolism, playing a role in nerve transmission, digestion, neuromuscular function, bones and teeth. The high calcium content found in OPN-F could be considered an alternative source, since the main food source (derived from milk) is not consumed sufficiently. Iron is also an essential mineral for the human body, used in the synthesis of haemoglobin, which carries oxygen in the form of myoglobin to the muscles. It is also essential for DNA synthesis and energy metabolism. The deficiency of this metal induces the occurrence of pathological conditions, with iron deficiency anaemia being the most frequent (Beard \& Dawson, 1997). Adding OPN-F, the carbohydrate content and $\mathrm{pH}$ of the final dough did not change significantly. Unexpected results of total protein content of F1 and F2 were observed. It was not possible to increase the protein content in the ratios applied in this study. It was associated to the lower content of the OPN flour added in F1 and F2 formulations and the OPN-F used in this work presented only $12.4 \%$ of total protein content, which is less than has been found in the literature, for example $28.4 \%$ by Takeiti et al. (2009) and $22.9 \%$ by Rocha et al. (2008).

The energy values were estimated based on the chemical composition of the pasta (control, F1 and F2) (Table 2). It was observed a nutritional advantage due to the energy values of the OPN products. If a portion of $80 \mathrm{~g}$ is considered - equivalent to a plate of dry pasta, the energy value of the pasta portion corresponds to $289.95 \mathrm{kcal}$ and $301.29 \mathrm{kcal}$ for F1 and F2, respectively. The conventional pasta had $317.10 \mathrm{kcal} 8 \mathrm{~g} \mathrm{~g}^{-1}$. Ferreira et al. (2016) found similar energy values for sorghum/rice/potato pasta and Zandonadi et al. (2012) for green banana pasta. The lower energy values of the OPN-F products are an extremely beneficial health factor in a world in which obesity and a sedentary lifestyle are causing widespread concern.

\subsection{Pasta quality}

Cooking performance is an important factor in a consumer's judgment of pasta quality. Reactions are produced during pasta cooking as a result of the heat effect and water uptake, for example protein swelling, starch gelatinization, increase in pasta weight and volume (Larrosa et al., 2016). The firmness, weight gain, cooking loss and colour parameters were evaluated (Table 3 ).

The pasta samples showed different behaviour after cooking. The control pasta presented the highest firmness $(1.31 \mathrm{~N})$. The addition of OPN-F reduced the firmness of the pasta (F1 and F2). This could be associated with the fibre presence in pasta network that could decrease the homogeneity and continuous gluten matrix formation. The wheat proteins are mainly composed of glutenin and gliadins that form inter- and intramolecular disulphide bonds during processing, forming a three-dimensional gluten network. This structure is responsible for the textural properties of pasta (Petitot et al., 2010). The addition of OPN, a non-gluten material could dilute the gluten strength promoting a weakened structure. The weight gain increased in the pasta containing OPN-F, it could be associated to the higher water absorption per gram of dry pasta. The weight gain of cooked pasta indicates the water uptake and corresponds to a macroscopic event involving a complex molecular modification of starch and proteins, mainly hydration (Nouviaire et al., 2008).

Cooking loss is related to the leakage of amylose from the starch granules, during cooking, which results in an unpleasant sticky texture (Mercier et al., 2016). It was widely used as an indicator of the overall cooking performance, indicating the resistance to disintegration during cooking pasta (Matsuo et al., 1992). A lower content of total solids in the cooking water was observed in F1. The values of the cooking loss of pasta enriched with OPN-F wee within the standards required for pasta. According to Hummel (1966), a cooking loss of up to $6 \%$ is characteristic of very good-quality wheat pasta, up to $8 \%$ of average-quality pasta, and values equal to or greater than $10 \%$ are characteristic of poor-quality pasta. Grzybowski \& Donnelly (1979) also consider 8\% as the maximum acceptable value for cooking loss in the cooking water.

Raw pasta has a gluten network that entrapped starch granules. After drying process of pasta, denaturation of gluten could sustain the desired protein cross-linking (Sissons, 2004). During the cooking process, the pasta matrix absorbs water and starch granules swell (increasing the volume), lose the rigid structure and release soluble substances. The degree of the openness of pasta gluten network would influence the extent of water absorption by starch granules during pasta cooking (Sun-Waterhouse et al., 2013).

The colour parameters of cooked pasta, given as $\mathrm{a}^{*}$ value (greenness to redness), $b^{*}$ value (blueness to yellowness), and $\mathrm{L}^{*}$ value (brightness), were measured in cooked pasta samples. The most of studies of the colour measurements on enriched pasta were performed on uncooked pasta, but it remains unclear

Table 3. Firmness, weight gain, cooking loss and colour parameters of pasta at different formulations.

\begin{tabular}{|c|c|c|c|c|c|c|}
\hline & \multirow{2}{*}{$\begin{array}{l}\text { Firmness } \\
(\mathrm{N})\end{array}$} & \multirow{2}{*}{ Weight gain (\%) } & \multirow{2}{*}{ Cooking loss (\%) } & \multicolumn{3}{|c|}{ Colour parameters } \\
\hline & & & & $\mathrm{L}^{*}$ & $\mathrm{a}^{*}$ & $\mathrm{~b}^{*}$ \\
\hline Control & $1.31 \pm 0.12^{\mathrm{a}}$ & $136.0 \pm 0.1^{\mathrm{a}}$ & $9.0 \pm 0.1^{\mathrm{a}}$ & $82.25 \pm 0.62^{a}$ & $-2.92 \pm 0.20^{\mathrm{a}}$ & $21.69 \pm 0.72^{\mathrm{a}}$ \\
\hline $\mathrm{F} 1$ & $0.76 \pm 0.07^{c}$ & $140.0 \pm 0.1^{\mathrm{a}}$ & $1.0 \pm 0.1^{\mathrm{c}}$ & $52.03 \pm 0.68^{\mathrm{b}}$ & $-1.49 \pm 0.22^{\mathrm{b}}$ & $21.50 \pm 0.80^{\mathrm{a}}$ \\
\hline $\mathrm{F} 2$ & $1.10 \pm 0.10^{\mathrm{b}}$ & $166.0 \pm 0.1^{\mathrm{a}}$ & $6.0 \pm 0.1^{\mathrm{b}}$ & $37.67 \pm 0.98^{c}$ & $-1.44 \pm 0.30^{\mathrm{b}}$ & $19.88 \pm 0.64^{\mathrm{b}}$ \\
\hline
\end{tabular}

Media with different letters in the column are significant different by Tukey's test $(\mathrm{p}<0.05)$. Firmness express in Newton $(\mathrm{N})$. 
whether the colour of the pasta before or after cooking has the most significant impact on consumer perception of the pasta (Mercier et al., 2016). Increasing the OPN-F concentration, the lightness $\left(\mathrm{L}^{*}\right)$ reduced significantly $(\mathrm{p}<0.05)$. This could be attributed to the pheophytinization process, the most common alteration of green leaves in food processing. The pheophytinization of chlorophyll and the consequent drastic colour shift of green OPN-F to the dull olive-brown pheophytin could be associated to the replacement of magnesium by hydrogen, but some shift in the resonance structure is also involved (Francis, 1985). The lightness decrease $\left(<L^{*}\right)$ in F1 and F2, proportional with the OPN-F concentration was followed by a concomitant decrease in the redness $\left(\mathrm{a}^{\star}\right)$ and yellowness $\left(\mathrm{b}^{\star}\right)$. In this work, the impact of enrichment with OPN-F on the yellowness of cooked pasta was greater than the impact on redness, presumably because $a^{*}$ values were lowest in control pasta and decreased with the OPN-F addition (F1 and F2 pasta).

The addition of OPN-F into pasta formulation promoted texture and colour (darkening) variation as compared to control pasta. These characteristics differ from the usual pasta product consumption, which could influence consumer acceptance.

\subsection{Sensorial analysis of pasta}

The sensorial analysis of the pasta was studied. Distributions of scores for appearance, odour, colour, flavour, texture and overall impression analysed by the judges are presented in Table 4. Among the 100 judges who received the pasta (control, F1 and F2), 92\% did not know of OPN and 98\% had never experienced any formulated product containing OPN. Most of the judges (34\%) eat pasta at least once a week, $26 \%$ eat at least twice a week, and $2 \%$ eat three times a week, which shows the importance of improving the nutritional quality of this product.

The control and F1 pasta were similar in colour, odour, texture and overall acceptability, which facilitate the entry into the pasta market. The sensorial parameters such as colour, flavour and texture are the main characteristics to acquisition, consumption, acceptance and preference of food products. The F1 showed higher acceptability in appearance, flavour and texture, and a higher decision-to-purchase score than F2 (Figure 2). Appearance is the most important food quality factor and colour is one of the main attributes of the appearance evaluated at the purchase time. The higher content of OPN-F in F2 promoted a darkness of pasta $\left(>L^{*}\right)$ that caused a negative effect on appearance. The colour of pasta is closely related to the colour properties of the raw material used in the formulations and changes in proportions of the ingredients may lead to different colours (Guimarães et al., 2018). On the other hand, texture is one of the main attributes of the food texture that is perceived during eating. The addition of $20 \%$ of OPN-F promoted a negative effect on the texture (F2 pasta formulation). This was reflected in texture sensorial notes confirming the results obtained in the instrumental analysis. Increasing the concentration of OPN-F resulted in a decrease in texture scores $(\mathrm{p}<0.05)$, and thus may related to the reduction in moisture observed in this samples. Previous studies have demonstrated that hardness decrease with the moisture content increase (Su et al., 2013). At higher substitution level, negative scores have been reported (Petitot et al., 2010).
Table 4. Appearance, colour, flavour, odour, texture and overall attributes evaluated by judges for the different formulations of pasta.

\begin{tabular}{cccc}
\hline \multirow{2}{*}{ Attributes } & \multicolumn{3}{c}{ Final media from judges } \\
\cline { 2 - 4 } & Control & F1 & F2 \\
\hline Appearance & $7.76 \pm 0.92^{\mathrm{a}}$ & $7.05 \pm 1.13^{\mathrm{b}}$ & $6.17 \pm 1.64^{\mathrm{c}}$ \\
Colour & $7.51 \pm 1.01^{\mathrm{a}}$ & $6.81 \pm 1.25^{\mathrm{ab}}$ & $6.15 \pm 1.71^{\mathrm{b}}$ \\
Flavour & $7.61 \pm 0.04^{\mathrm{a}}$ & $7.57 \pm 0.99^{\mathrm{b}}$ & $6.90 \pm 1.30^{\mathrm{c}}$ \\
Odour & $7.20 \pm 1.19^{\mathrm{a}}$ & $6.97 \pm 1.08^{\mathrm{ab}}$ & $6.50 \pm 1.50^{\mathrm{b}}$ \\
Texture & $7.59 \pm 0.98^{\mathrm{a}}$ & $7.46 \pm 1.18^{\mathrm{a}}$ & $6.87 \pm 1.45^{\mathrm{b}}$ \\
Overall & $7.53 \pm 0.92^{\mathrm{a}}$ & $7.44 \pm 0.91^{\mathrm{a}}$ & $6.74 \pm 1.17^{\mathrm{b}}$ \\
\hline
\end{tabular}

Media with different letters in the same line are significant different by Tukey's test $(\mathrm{p}<0.05)$.

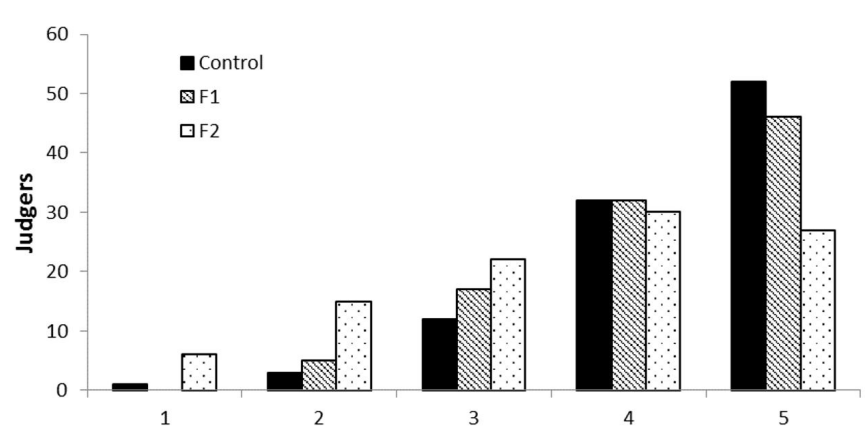

Figure 2. Consumer purchase intention in relation to pasta formulations with and without OPN-F enrichment. (1) Certainly would not buy; (2) Possibly would not buy; (3) Maybe would not buy, or not; (4) Possibly would buy; (5) Certainly would buy.

Regarding the purchase decision, the judges showed a resistance to the formulation with $20 \%$ of OPN-F (F2) and this is could be associated with the fibrous texture and characteristic flavour of the plant. The average score for F1 was 4 out of 5 , or $80.0 \%$ acceptance, while F2 showed $63.2 \%$ acceptance among 100 judges. According to Stone \& Sidel (2004), an acceptance ratio higher than or equal to $70 \%$ is considered acceptable. In this research, the acceptance score of pasta products with OPN-F content (F1 and F2) could be related to the texture and flavour due to the fibre addition.

The search for healthier foods that promote wellness and healthy has generated a new market in food sector. Although, it is still necessary to give more information of these new ingredients before introduce in daily diet. Sensorial evaluation of fortified pasta focused on the overall product acceptability. In general, the additions up to 10\% chickpea flour (Wood, 2009), lupin flour (Torres et al., 2007), were generally well accepted. At higher substitution level, negative scores have been reported (Petitot et al., 2010). Rocha et al. (2008) developed a pasta containing $2 \%$ of OPN-F and obtained, by sensorial analysis using 80 volunteers, $92 \%$ of acceptability. Silva et al. (2015) produced bread containing $5 \%$ of OPN-F and affirmed that additions of small amounts of OPN-F were well accepted by the judges.

\section{Conclusions}

The addition of OPN-F improved the nutritional quality of pasta in terms of dietary fibre, calcium, iron compared to the control pasta. Pasta enriched with OPN-F presented a greenish 
and fibrous appearance. Sensory evaluations indicated that pasta enriched with $10 \%$ of OPN-F did not affect consumer acceptance. The formulation containing $10 \% \mathrm{OPN}-\mathrm{F}$ presented characteristics closer to conventional pasta in relation to colour, texture and overall impression. Unexpected results of total protein content of F1 and F2 were observed that it was associated to the lower content of protein of OPN-F used in this work. The new product has the potential to be taken to prevent constipation, obesity (high satiety due the dietary fibre content) and still be an alternative intake of calcium and iron. The product showed excellent parameters in relation to cooking quality and were within the standards established. The firmness of pasta decreased with the addition of OPN-F. Sensory analysis has shown that the most judges were not aware of the OPN leaves and frequently consumed pasta, highlighting the importance of improving the nutritional quality of this product.

\section{Acknowledgements}

This work was supported by the CNPq (National Council for Scientific and Technological Development, Brazil) and FAPESP (São Paulo Research Foundation, Brazil).

\section{References}

Abdel-Aal, E. S. M., \& Hucl, P. (2002). Amino acid composition and in vitro protein digestibility of selected ancient wheats and their end products. Journal of Food Composition and Analysis, 15(6), 737-747. http://dx.doi.org/10.1006/jfca.2002.1094.

Almeida, J. Fo., \& Cambraia, J. (1974). Estudo do valor nutritivo do "Ora-pro-nobis" (Pereskia aculeata Mill.). Revista Ceres, 21(114), $105-111$.

Association of Official Analytical Chemists - AOAC. (2012). International official methods of analysis of AOAC. Gaithersburg: AOAC.

Beard, J. L., \& Dawson, H. D. (1997). Handbook of nutritionally essential mineral elements. In B. L. O’Dell \& R. A. Sunde (Eds.), Iron (pp. 275-334). New York: CRC Press.

Conceição, M. C., Junqueira, L. A., Silva, K. C. G., Prado, M. E. T., \& Resende, J. V. (2014). Thermal and microstructural stability of a powdered gum derived from Pereskia aculeata Miller leaves. Food Hydrocolloids, 40, 104-114. http://dx.doi.org/10.1016/j. foodhyd.2014.02.015.

Dayrell, M. S., \& Vieira, E. C. (1977). Leaf protein concentrate of the cactacea Pereskia aculeata Mill. I. Extraction and composition. Nutrition Reports International, 15(5), 529-537. http://dx.doi. org/10.1590/S0101-20612008000400013.

Ferreira, S. M. R., Mello, A. P., Anjos, M. C. R., Krüger, C. C. H., Azoubel, P. M., \& Alves, M. A. O. (2016). Utilization of sorghum, rice, corn flours with potato starch for the preparation of gluten-free pasta. Food Chemistry, 191, 147-151. http://dx.doi.org/10.1016/j. foodchem.2015.04.085. PMid:26258714.

Ficco, D. B. M., Simone, V., Leonardis, A. M., Giovanniello, V., Del Nobile, M. A., Padalino, L., Lecce, L., Borelli, G. M., \& De Vita, P. (2016). Use of purple durum wheat to produce naturally functional fresh and dry pasta. Food Chemistry, 205, 187-195. http://dx.doi. org/10.1016/j.foodchem.2016.03.014. PMid:27006230.

Francis, F. J. (1985). Food chemistry. In O. R. Fennema (Ed.), Pigments and other colorants (pp. 545-584). New York:Marcel Dekker.

Guimarães, R. M., Silva, T. E., Lemes, A. C., Boldrin, M. C. F., Silva, M. A. P., Silva, F. G., \& Egea, M. B. (2018). Okara: A soybean by-product as an alternative to enrich vegetable paste. Lebensmittel-Wissenschaft + Technologie, 92, 593-599. http://dx.doi.org/10.1016/j.lwt.2018.02.058.

Grzybowski, R. A., \& Donnelly, B. J. (1979). Cooking properties of spaghetti: factors affecting cooking quality. Journal of Agricultural and Food Chemistry, 27(2), 380-384. http://dx.doi.org/10.1021/ jf60222a045.

Heller, M. C., Keoleian, G. A., \& Willett, W. C. (2013). Toward a lifecycle-based, diet-level framework for food environmental impact and nutritional quality assessment: a critical review. Environmental Science \& Technology, 47(22), 12632-12647. http://dx.doi.org/10.1021/ es4025113. PMid:24152032.

Hummel, C. (1966). Macaroni products: manufacture, processing, and packaging (2nd ed.). London: Food Trade Press.

Khan, I., Yousif, A., Johnson, S. K., \& Gamlath, S. (2013). Effect of sorghum flour addition on resistant starch content, phenolic profile and antioxidant capacity of durum wheat pasta. Food Research International, 54(1), 578-586. http://dx.doi.org/10.1016/j. foodres.2013.07.059.

Kinupp, V. F., \& Lorenzi, H. (2014). Plantas Alimentícias Não Convencionais (PANC) no Brasil: guia de identificação, aspectos nutricionais e receitas ilustradas. Nova Odessa: Instituto Plantarum de Estudos da Flora.

Krishnan, J. G., Menon, R., Padmaja, G., Sajeev, M. S., \& Moorthy, S. N. (2012). Evaluation of nutritional and physico-mechanical characteristics of dietary fiber-enriched sweet potato pasta. European Food Research and Technology, 234(3), 467-476. http://dx.doi. org/10.1007/s00217-011-1657-8.

Larrosa, V., Lorenzo, G., Zaritzky, N., \& Califano, A. (2016). Improvement of the texture and quality of cooked gluten-free pasta. LebensmittelWissenschaft + Technologie, 70, 96-103. http://dx.doi.org/10.1016/j. lwt.2016.02.039.

Maciel, V. B. V., Yoshida, C. M. P., \& Franco, T. T. (2015). Chitosan/pectin polyelectrolyte complex as a $\mathrm{pH}$ indicator. Carbohydrate Polymers, 132, 537-545. http://dx.doi.org/10.1016/j.carbpol.2015.06.047. PMid:26256380.

Matsuo, R., Malcolmson, L., Edwards, N., \& Dexter, J. (1992). A colorimetric method for estimating spaghetti cooking losses. Cereal Chemistry, 69(1), 27-29.

Mercê, A. L. R., Landaluze, J. S., Mangrich, A. S., Szpoganicz, B., \& Sierakowski, M. R. (2001). Complexes of arabinogalactan of Pereskia aculeata and $\mathrm{Co} 2+, \mathrm{Cu} 2+, \mathrm{Mn} 2+$, and $\mathrm{Ni} 2+$. Bioresource Technology, 76(1), 29-37. http://dx.doi.org/10.1016/S0960-8524(00)00078-X. PMid:11315807.

Mercier, S., Moresoli, C., Mondor, M., Villeneuve, S., \& Marcos, B. (2016). A meta-analysis of enriched pasta: what are the effects of enrichment and process specifications on the quality attributes of pasta? Comprehensive Reviews in Food Science and Food Safety, 15(4), 685-704. http://dx.doi.org/10.1111/1541-4337.12207.

Miceli, A., Francesca, N., Moschetti, G., \& Settanni, L. (2015). The influence of addition of Borago officinalis with antibacterial activity on the sensory quality of fresh pasta. International Journal of Gastronomy and Food Science, 2(2), 93-97. http://dx.doi.org/10.1016/j. ijgfs.2014.12.004.

Nobel, P. S., \& Hartsock, T. L. (1986). Leaf and stem $\mathrm{CO}_{2}$ uptake in the three subfamilies of the cactaceae. Plant Physiology, 80(4), 913-917. http://dx.doi.org/10.1104/pp.80.4.913. PMid:16664741.

Nouviaire, A., Lancien, R., \& Maache-Rezzoug, Z. (2008). Influence of hydrothermal treatment on rheological and cooking characteristics of fresh egg pasta. Journal of Cereal Science, 47(2), 283-291. http:// dx.doi.org/10.1016/j.jcs.2007.04.014. 
Oliviero, T., \& Fogliano, V. (2016). Food design strategies to increase vegetable intake: the case of vegetable enriched pasta. Trends in Food Science \& Technology, 51, 58-64. http://dx.doi.org/10.1016/j. tifs.2016.03.008.

Padalino, L., Mastromatteo, M., Lecce, L., Cozzolino, F., \& Del Nobile, M. A. (2013). Manufacture and characterization of gluten-free spaghetti enriched with vegetable flour. Journal of Cereal Science, 57(3), 333-342. http://dx.doi.org/10.1016/j.jcs.2012.12.010.

Paucar-Menacho, L. M., Silva, L. H., Barretto, P. A. A., Mazal, G., Fakhouri, F. M., Steel, C. J., \& Collares-Queiroz, F. P. (2008). Development of functional fresh food adding soy protein isolate and polidextrose using paprika as coloring agent. Food Science and Technology, 28(4), 767-778. http://dx.doi.org/10.1590/S0101-20612008000400002.

Petitot, M., Boyer, L., Minier, C., \& Micard, V. (2010). Fortification of pasta with split pea and faba bean flours: pasta processing and quality evaluation. Food Research International, 43(2), 634-641. http://dx.doi.org/10.1016/j.foodres.2009.07.020.

Pinto, N. C. C., \& Scio, E. (2014). The biological activities and chemical composition of Pereskia species (Cactaceae): a review. Plant Foods for Human Nutrition, 69(3), 189-195. http://dx.doi.org/10.1007/ s11130-014-0423-z. PMid:24862084.

Rocha, D. R. C., Pereira, G. A., Jr., Vieira, G., Pantoja, L., Santos, A. S., \& Pinto, N. A. V. D. (2008). Macarrão adicionado de ora-pro-nóbis (Pereskia aculeata Miller) desidratado. Brazilian Journal of Food and Nutrition, 19(4), 459-465.

Sierakowski, M. R., Gorin, P. A. J., Reicher, F., \& Corrêa, J. B. C. (1987). Some structural features of a heteropolysaccharide from the leaves of the cactus Pereskia aculeata. Phytochemistry, 26(6), 1709-1713. http://dx.doi.org/10.1016/S0031-9422(00)82273-6.

Silva, D. O., Primio, E. M., Botelho, F. T., \& Gularte, M. A. (2015). Valor nutritivo e análise sensorial de pão de sal adicionado de Pereskia aculeata. DEMETRA: Food Nutrition and Health, 9(4), 1027-1040.

Sissons, M. J. (2004). Encyclopedia of grain science. In C. Wrigley, H. Corke \& C. Walker (Eds.), Pasta (pp. 409-418). North Ryde: Elsevier.

Sobrinho, S. S., Costa, L. L., Gonçalves, C. A. A., \& Campagnol, P. C. B. (2015). Emulsified cooked sausage enriched with flour from ora-pro-nobis leaves (Pereskia aculeate Miller). International Food Research Journal, 22(1), 318-323.

Stone, H., \& Sidel, J. L. (2004). Sensory evaluation practices (3rd ed.). San Diego: Elsevier Academic Press.

Su, S. I. T., Yoshida, C. M. P., Contreras-Castillo, C. J., Quiñones, E. M., \& Venturini, A. C. (2013). Okara, a soymilk industry by-product, as a non-meat protein source in reduced fat beef burgers. Food Science and Technology (Campinas), 33(1), 52-56. http://dx.doi.org/10.1590/ S0101-20612013000500009.

Sun-Waterhouse, D., Jin, D., \& Waterhouse, G. I. N. (2013). Effect of adding elderberry juice concentrate on the quality attributes, polyphenol contents and antioxidant activity of three fibre-enriched pastas. Food Research International, 54(1), 781-789. http://dx.doi. org/10.1016/j.foodres.2013.08.035.

Takeiti, C. Y., Antonio, G. C., Motta, E. M., Collares-Queiroz, F. P., \& Park, K. J. (2009). Nutritive evaluation of non-conventional leafy vegetable (Pereskia aculeata Miller). International Journal of Food Sciences and Nutrition, 60(1, Suppl 1), 148-160. http://dx.doi. org/10.1080/09637480802534509. PMid:19468927.

Tazrart, K., Lamacchia, C., Zaidi, F., \& Haros, M. (2016). Nutrient composition and in vitro digestibility of fresh pasta enriched with Vicia faba. Journal of Food Composition and Analysis, 47, 8-15. http:// dx.doi.org/10.1016/j.jfca.2015.12.007.

Torres, A., Frias, J., Granito, M., Guerra, M., \& Vidal-Valverde, C. (2007). Chemical, biological and sensory evaluation of pasta products supplemented with alpha- galactoside-free lupin flours. Journal of the Science of Food and Agriculture, 87(1), 74-81. http:// dx.doi.org/10.1002/jsfa.2673.

Wood, J. A. (2009). Texture, processing and organoleptic properties of chickpea- fortified spaghetti with insights to the underlying mechanisms of traditional durum pasta quality. Journal of Cereal Science, 49(1), 128-133. http://dx.doi.org/10.1016/j.jcs.2008.07.016.

Zandonadi, R. P., Botelho, R. B. A., Gandolfi, L., Ginani, J. S., Montenegro, F. M., \& Pratesi, R. (2012). Green banana pasta: an alternative for gluten-free diets. Journal of the Academy of Nutrition and Dietetics, 112(7), 1068-1072. http://dx.doi.org/10.1016/j.jand.2012.04.002. PMid:22889636. 